\title{
Preface
}

\section{Toward Responsibility for a Cooperative "East Asian Era:" \\ New Developments in Cultural Interaction Studies in East Asia}

\begin{abstract}
WANG Min*
This could be called the era of East Asia. East Asia could increase its momentum even more if it heightened cooperation in a variety of areas. An increase in our awareness of the issue of what role we should play for further cooperation is expected. Efforts are being made in every field, but the possibility that cultural cooperation can precede all other areas is high. Cultural interaction studies in East Asia are evidence of this. There are already many examples of positive results. I learned of Kaiseimachi in Kanagawa Prefecture at the 2006 " $21^{\text {st }}$ Century Kanagawa Roundtable Conference," and was told that Kaiseimachi is researching traces in local history in the Ashigara region of the legendary Chinese ruler who introduced flood control, $\mathrm{Yu}$ the Great. The fact that $\mathrm{Yu}$ the Great, a protagonist from ancient Chinese history, had crossed to Japan and had been beloved for over one-thousand years, cannot be emphasized enough as a good example of historical and modern values that bespeak cooperation in East Asian culture.

Kaiseimachi lies at the foot of Mt. Fuji, the symbol of Japan. It is of profound interest that in June, 2013, Mt. Fuji was registered not as a natural heritage site, but as a cultural world heritage site out of the three categories of natural, cultural, and compound world heritage sites. It is considered "a symbol of a sacred place and artistic inspiration." Twenty-five sites, including sacred areas at the summit and Fuji Five Lakes, are called Mt. Fuji heritage assets (as an aside, there are eighteen world heritage sites in Japan as of 2015). In terms of China, the symbols that all Japanese know could be listed as Yao, Shun, Wu, Confucius, and other "saints." If we search in Japan for a symbol common to both Japan and China, it is the Ashigara region of Kaiseimachi! Although it is a coincidence that Mt. Fuji and Yu the Great are both in the same area, it is profoundly interesting.

In the Ashigara region, there are still remnants of Yu culture, such as the

* Wang Min 王敏 is a Professor at Hosei University and President of the Society for Interaction in East Asian Studies.
\end{abstract}


temple dedicated to Yu the Great (now Fukuzawa Shrine) built in 1726, the related Bunmei monument (Bunmei is an alternate name for Yu the Great), and the Bunmei festival, that are still extant today. Of course, Yu the Great culture in Japan has been adapted to the clime and lifestyles of Japan through Japanese transplantation and selection. Although changed in form, it was probably promoted to a deity in the Japanese belief system even as it continued to have a Sino-Japanese syncretic cultural character. In any case, it bloomed in the soil of Japanese culture as belief in Yu the Great, which can be considered a symbol of the Ashigara region.

The reason the venue selected for the Seventh Annual Meeting of the Society for Cultural Interaction in East Asia held on May 9, 2015 was Kaiseimachi was because the sites of Mt. Fuji and Yu the Great could both be seen there. If we expand our thinking somewhat and go back in history, I am certain we will be able imagine the original landscape where East Asian culture was in contact, penetrated, collided, adapted, and merged. While spreading in all directions, cultural interaction continued through repeated trial and error, to become the cultural landscape that was constructed from historical and cultural accumulation. Further, we should also be able to notice that infrastructure related to $\mathrm{Yu}$ the Great has suffused the daily lives of modern man. For example, festivals for different times of the calendar, facilities such as schools that foster future generations, irrigation canals that are the lifeline of cities, and bridges over rivers, could all be said to embody $\mathrm{Yu}$ the Great as part of the cultural climate.

$\mathrm{Yu}$ the Great in Japan is usually considered a god that controls flooding. A local citizens' group in Ashigara has been central to discovering historical relics of the culture of $\mathrm{Yu}$ the Great as a Japanese god of flood control. Through fieldwork conducted from 2007 to the present, 90 sites of the Japanese god of flood control have been discovered in Japan, from Hokkaido to Kyūshū to Okinawa. At the very least, in terms of analyzing Japan's modern values of hybrid culture, there has been no better example of concrete research. It is extremely valuable.

$\mathrm{Yu}$ the Great culture has been connecting Japan and China for over a thousand years. This is true not just for Japan and China; Yu culture spread ties throughout East Asia and has come to be a common culture. I thought that research concerning this topic was not only useful for analyzing SinoJapanese cultural relations, but could be a unique contribution to the academic field of East Asian cultural interaction studies. In particular, when $\mathrm{Yu}$ the Great is understood as the foundation of the architecture for intellectual knowledge in East Asia and as a symbol of Sinographic civilization, the 808 common Sinographs to Japan, China, and Korea hammered out under the leadership of the Trilateral Culture Ministers' Meeting (former Prime Minister 
Fukuda Yasuo is the representative for Japan), could be said to be a new creative evolution that transcends the time and space of over a thousand years.

The common undercurrent of Yu the Great culture is a flow of knowledge. People read this dynamically, understood it, and integrated a variety of methods in numerous fields, such as the humanities, sociology, and science. Through elucidating multifaceted points of view, they more than likely felt the cultural exchange more palpably and intimately. The fact that such research on $\mathrm{Yu}$ has achieved the status of a topic in East Asian intercultural studies should be understood as an achievement made possible by the constructive development of the conference. We can acknowledge this as a valuable step in the quest for scholarship with possibilities for cooperative research with local regions and private citizens. Research is comprised of both macroscopic and microscopic elements. I am certain that borderless linked efforts have honed the direction and productivity of learning.

It is appropriate that the Seventh Annual Meeting of the Society for Cultural Interaction in East Asia was held in Kaiseimachi, which has the double symbols of Mt. Fuji and Yu the Great. It allowed us to speak of the sound progress of the conference. I am confident that progress in research on Yu the Great and East Asian cultural interaction studies will gain momentum. Further, with multidimensional interaction between the Society members, specialists, private sector researchers, participants from abroad and Japanese citizens, I sincerely hope that we will continue to develop interactively through mutual enhancement.

In conclusion, on May 3, just before the conference, I was blessed with the opportunity of meeting the Emperor and Empress. I was grateful to receive warm encouragement for my academic research and humanist exchanges. I am resolved to transform their words, which went to my heart, into energy for the future.

I hereby express my gratitude to the Society board members and staff of the East Asia Cultural Interaction Studies office, as well as for participation by both locals and those from abroad. I will keep in mind that it was your observations and instructions that made everything possible.

Thank you! Arigatō gozaimasu! (ありがとうございます!) Kamsahamnida! (감사 합니다!) Xie Xie! (謝謝!) 


\section{Appendix 1}

Yu the Great and the Japanese, (NHK Publishers, December, 2014)

\section{Appendix 2}

Newspaper article on the opening of the conference: May 12, 2015 Kanagawa Shimbun (see attached file)

\section{Appendix 3}

Related articles introducing the subject in China:

"Zai Dongying xiaozhen ganshou Dayu wenhua chuanbo 'shenji”" 在东瀛小镇感

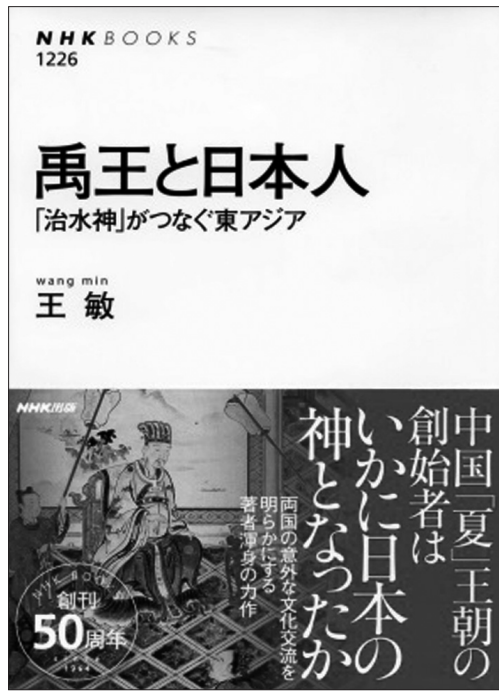
受大禹文化传播 “神迹” (Small Village in Japan Impressed by Spread of Yu the Great Culture: Sacred Sites") 1. http://www.tibet.cn/news/gjxw/201505/t20150510_2863048.htm

2. Newspaper photos: "Riben Fushishanlu liucun de Dayu wenhua liuchuan: “shenji”” 日本富士山麓留存的大禹文化流传 “神迹” (Spread of Yu the Great Culture Preserved at the Foot of Mt. Fuji in Japan: Sacred Sites) http://japan.people.com.cn/n/2015/0511/c35465-26978906-3.html

3. Above articles reprinted in the following major news sources in China:

Xinhuanet, Chinanews.com, People's Daily Online, Huanqiu.com, China.org., Taiwan.cn., SINA, NetEase, Sohu.com., Ifeng.com., Jfdaily, DZWWW.com., Dahe.cn., Xinmin.cn., js.chinanews.com., Anhui Radio and TV Station, etc.

\section{Appendix 4}

Japanese-language articles disseminated from China

1. Beijing Review (Japanese version):

http://japanese.beijingreview.com.cn/ztj1/txt/2015-05/11/content_687253. htm

2. Articles reprinted on the Chinese internet: http://japanese.china.org.cn/jp/txt/2015-05/11/content_35540961.htm 